\title{
Feeding supply of suckling Martinik ewes reared in intensive conditions: effects of supplement levels and litter size
}

\author{
Gisèle Alexandre*, Harry Archimède, Eric Chevaux, \\ Gilles AumONT, Alain XANDÉ \\ INRA, Unité de Recherches Zootechniques, Centre Antilles-Guyane, \\ 97170 Domaine Duclos, Petit Bourg, Guadeloupe, France
}

(Received 6 January 2000; accepted 10 April 2001)

\begin{abstract}
Experiments were carried out to determine the effects of supplementation upon milk production and growing performances of Martinik hair sheep. Ewes weighing $49 \mathrm{~kg} \mathrm{LW}$ were used in a 2-season experimental study. In the first trial, 3 energy supplement levels were offered to ewes suckling single lambs. The adjusted level (A, 8 ewes) was supplied to ensure that the litter had a daily weight gain (DWG) of $250 \mathrm{~g}$. High (H, 8 ewes) and low (L, 8 ewes) levels were $150 \%$ and $75 \%$ of level A, respectively. In the second trial, comparative use of the $\mathrm{H}$ level was studied with 3 animal requirement levels: ewes suckling single lambs (SI, same ewes as H ewes), twins (TW, 8 ewes) and triplets (TR, 6 ewes), respectively. The experimental design was replicated in a second lambing season. The basal diet was chopped Digitaria decumbens hay (0.6 UFL, $4.6 \% \mathrm{CP})$ offered ad libitum. Supplements were composed of maize $(65 \%)$, soya bean (3\%), fish meal $(8 \%)$ and dehydrated alfalfa (24\%). The milk production (MP) of ewes on the L diet was lower $(P<0.05)$ than that of ewes on the $A$ and $\mathrm{H}$ diets: 1142,1415 and $1518 \mathrm{~g} \cdot \mathrm{d}^{-1}$, respectively. H-fed ewes fattened during the lactating period while $\mathrm{A}$ and $\mathrm{L}$ ewes respectively maintained and lowered their body condition score (BCS). Differences recorded for lamb DWG were low, but this trait reached a maximum of $248 \mathrm{~g} \cdot \mathrm{d}^{-1}$. MP varied significantly $(P<0.05)$ according to the litter size. Individual DWG was different for single, twin and triplet lambs $(P<0.001): 261,188$ and $143 \mathrm{~g} \cdot \mathrm{d}^{-1}$, respectively. In intensive breeding conditions, recommended daily energy allowances taking into account a good BCS of ewes for successive reproduction are 1.47 UFL for single-suckling ewes and 2.17 UFL for twin-suckling ewes, in order to obtain a DWG of the litter of 250 and $400 \mathrm{~g} \cdot \mathrm{d}^{-1}$, respectively.
\end{abstract}

Martinik ewes / supplementation / milk production / pre-weaning growth

Résumé - Alimentation des brebis allaitantes Martinik élevées dans des conditions intensives : effets de différents niveaux de concentrés ou de la taille de portée. L'effet de la complémentation sur les performances des ovins allaitants a été étudié chez les brebis à poils Martinik pesant $49 \mathrm{~kg}$ de

* Correspondence and reprints

Tel: 33 (0)5 902559 33; fax: 33 (0)5 9025 59 36; e-mail: alexandre@ antilles.inra.fr 
poids vif. Dans un premier essai, trois niveaux énergétiques ont été comparés chez les brebis allaitant un agneau. Le niveau ajusté (A, 8 brebis) a été apporté pour assurer un gain moyen quotidien (GMQ) théorique de $250 \mathrm{~g} \cdot \mathrm{j}^{-1}$. Les niveaux bas (B, 8 brebis) et haut (H, 8 brebis) représentaient 75 et $150 \%$ de $\mathrm{A}$, respectivement. Dans un deuxième essai, un gradient de besoins a été testé chez les brebis recevant la ration $\mathrm{H}$, à portée simple $(\mathrm{S}$, mêmes brebis que celles de l'essai 1$)$, double $(\mathrm{D}, 8$ brebis) et triple (T, 6 brebis). Le schéma expérimental a été répété lors d'une deuxième saison de mise-bas. Les animaux recevaient ad libitum du foin de Digitaria decumbens (0,6 UFL, 4,6 \% MAT). Le concentré était composé de maïs $(65 \%)$, de farine de soja (3\%), de farine de poisson (8\%) et de luzerne déshydratée $(24 \%)$. La production laitière (PL) des brebis recevant la ration $\mathrm{B}$ a été plus faible $(P<0,05)$ que celle des brebis des lots A et $\mathrm{H}: 1142,1415$ et $1718 \mathrm{~g} \cdot \mathrm{j}^{-1}$, respectivement. Les notes d'état corporel (NEC) ont diminué, stagné et augmenté pour les brebis des lots B, A et H, respectivement. Le GMQ des agneaux simples a été peu différent entre les rations et a atteint au maximum $248 \mathrm{~g}$ pour le lot H. La PL des brebis de taille de portée multiple a été supérieure de $30 \%$ à celle des brebis à portée simple. Le GMQ des portées doubles a été voisin de $400 \mathrm{~g}$. Des recommandations sont formulées dans le cas d'un élevage intensif : 1,47 et $2,17 \mathrm{UFL} \cdot \mathrm{j}^{-1}$ pour des brebis pesant près de $50 \mathrm{~kg}$ et allaitant respectivement un et deux agneaux.

brebis Martinik / complémentation / production laitière / croissance / zone tropicale

\section{INTRODUCTION}

In the French West Indies, sheep production is based on farming hair sheep of the Martinik breed [11]. This genotype is similar to those of the other islands of the Caribbean including the Barbados Blackbelly, Cuban Pelibuey, and others such as Saint Martin and Virgin Island White of the Lesser Antilles [15]. Grazing is the most common mode of animal production in the Caribbean. For flocks which graze throughout the year, the fertility, prolificacy and preweaning mortality rates are $88 \%, 180 \%$ and $10 \%$, respectively. The pre-weaning growth of lambs varies from 150 to $180 \mathrm{~g} \cdot \mathrm{d}^{-1}$ [14]. However, tropical forage, even when exploited intensively, is of average food value [4] and is a major limiting factor in animal production. High levels of productivity partly depend on the supplementary intake of more energy-rich foods. Very few studies deal with the suckling system although this is the basis of meat production. It is necessary to determine the level of energy intake required for high productivity. The aims of this study are firstly to test the effects of different supplement levels on the performances of suckling ewes and secondly to compare production requirement levels at the same feeding supply level.

\section{MATERIALS AND METHODS}

The study was conducted on the Duclos Experimental Farm of the INRA Animal Production Research Unit in Guadeloupe, characterised by a humid tropical climate with an annual rainfall of $2860 \mathrm{~mm}$ and an average temperature of $25^{\circ} \mathrm{C}$.

\subsection{Animals}

Thirty-eight suckling Martinik ewes weighing on average $49.0 \pm 4.6 \mathrm{~kg}$ were monitored during 2 successive seasons (S1 and S2). At birth, they were placed with their lamb(s) in individual pens on a slatted floor. At each season, two trials were conducted at the same time. In trial 1, three supplement levels were compared in singlesuckling ewes. In trial 2 , requirement levels (3 litter sizes) were tested with ewes receiving a high supplement level. Groups of animals were determined according to their litter size, parity (primiparous vs. multiparous), 
Table I. Composition of groups and live weight traits of Martinik ewes according to reproduction season (S1 or S2), litter size (single or twins) and energy supplement levels (low, adjusted or high).

\begin{tabular}{|c|c|c|c|c|c|c|}
\hline Trial & $\begin{array}{c}\text { Number } \\
\text { of ewes } \\
\text { per season }{ }^{1}\end{array}$ & $\begin{array}{l}\text { Litter } \\
\text { size }\end{array}$ & $\begin{array}{l}\text { Supplement } \\
\text { level }\end{array}$ & $\begin{array}{l}\text { Theoretical } \\
\mathrm{DWG}^{2}(\mathrm{~g}) \\
\text { of the litter }\end{array}$ & $\begin{array}{c}\mathrm{LW}^{3} \\
\text { of the ewes } \\
(\mathrm{kg})\end{array}$ & $\begin{array}{c}\mathrm{BW}^{4} \\
\text { of the litter } \\
(\mathrm{kg})\end{array}$ \\
\hline 1 & 4 & Single & Low & 150 & 47.1 & 3.5 \\
\hline 1 & 4 & Single & Adjusted & 250 & 48.5 & 3.7 \\
\hline 2 & 4 & Single & High & 400 & 49.5 & 3.6 \\
\hline 2 & 4 & Twins & High & 400 & 51.9 & 7.5 \\
\hline 2 & 3 & Triplets & High & 400 & 49.8 & 10.0 \\
\hline
\end{tabular}

${ }^{1}$ The trials were repeated in two successive lambing seasons with different ewes; ${ }^{2}$ DWG: daily weight gain, dietary intake calculated according to the recommendations of Bocquier et al. [7]; ${ }^{3} \mathrm{LW}$ : live weight; ${ }^{4} \mathrm{BW}$ : live weight at birth.

live weight, body condition and the weight of the litter at birth (Tab. I).

\subsection{Feeding supply}

The basal diet was chopped Digitaria decumbens (Pangola) hay distributed ad libitum (10 to $20 \%$ of refusal allowed). During trial 1, three diets were tested (Tab. II). The adjusted level (A) was calculated according to the recommendations of Bocquier et al. [7] to ensure a theoretical growth of the litter of $250 \mathrm{~g} \cdot \mathrm{d}^{-1}$, a growth of $150 \mathrm{~g} \cdot \mathrm{d}^{-1}$ for the low level (L) and of $400 \mathrm{~g} \cdot \mathrm{d}^{-1}$ for the high level $(\mathrm{H})$. The supplement was composed of maize $(65 \%)$, dehydrated alfalfa pellets $(24 \%)$, fish meal $(8 \%)$ and soya bean cake (3\%). The chemical composition of the hay and the feed supplement is given in Table III. The UFL and PDI values of the Pangola hay for the two seasons were estimated [4] at 0.60 and $36 \mathrm{~g} \cdot \mathrm{kg}^{-1} \mathrm{DM}$, respectively. The values of the supplement [10] were 1.14 and $113 \mathrm{~g} \cdot \mathrm{kg}^{-1} \mathrm{DM}$, respectively.

The ewes had an initial 14 days to adapt to the hay and the quantities of supplement. The lambs had free access separately to a growth concentrate (maize $80 \%$, fish meal $17.5 \%$, minerals/vitamins $2.5 \%$ ) from the age of one month.

\subsection{Measurements}

The quantities of fodder distributed and refused were weighed every day, 5 days a

Table II. Quantities of feed distributed to suckling Martinik ewes according to supplement level and lactation stage (weeks).

\begin{tabular}{|c|c|c|c|c|c|c|}
\hline \multirow{2}{*}{$\begin{array}{l}\text { Levels } \\
\text { Lactation stage }\end{array}$} & \multicolumn{2}{|c|}{ Low } & \multirow{2}{*}{\multicolumn{2}{|c|}{$\frac{\text { Adjusted }}{1-3 \text { weeks } 4-6 \text { weeks }}$}} & \multicolumn{2}{|c|}{ High } \\
\hline & $1-3$ weeks & 4-6 weeks & & & $1-3$ weeks & 4-6 weeks \\
\hline $\begin{array}{l}\text { Supplement } \mathrm{g} \cdot \mathrm{d}^{-1} \\
\text { Hay, water and VMS* }\end{array}$ & 1050 & 780 & $\begin{array}{l}1350 \\
\text { ad li }\end{array}$ & $\begin{array}{l}1050 \\
\text { jitum }\end{array}$ & 2000 & 1700 \\
\hline
\end{tabular}

* Vitamin and mineral supplement in the form of a salt block composed of $\mathrm{Ca}(6 \%), \mathrm{P}(2 \%), \mathrm{Mg}(1 \%), \mathrm{Na}(28 \%)$ and $\mathrm{Mn}, \mathrm{Fe}, \mathrm{I}, \mathrm{Co}, \mathrm{Se}$. 
Table III. Chemical composition of the feed distributed to the suckling Martinik ewes.

\begin{tabular}{lcc}
\hline Variable & Pangola hay & Feed supplement \\
\hline Dry matter $\left(\mathrm{g} \cdot \mathrm{kg}^{-1}\right)$ & 869 & 916 \\
Total crude protein & 45.8 & 200.8 \\
NDF & 765.5 & 213.8 \\
ADF & 401.1 & 96.2 \\
ADL & 43.1 & 12.0
\end{tabular}

NDF: neutral detergent fibre; ADF: acid detergent fibre; ADL: acid detergent lignin (Van Soest et al. 1997; [20]).

week. The ewes were treated every week according to the oxytocin method [8] adapted to Martinik sheep [14]. A body condition score (BCS), assessed by two scorers, was attributed to each female on the same day, according to the Russel method [16]. The lambs were weighed at birth, then each week; the ewes were weighed at the beginning and end of the trial. The values reported in this study refer to weeks 3,4 , 5 and 6 of lactation, that is, after 2 weeks for the ewes to adapt to the individual pen and the diet.

\subsection{Chemical and statistical analyses}

The dry matter of the hay, the feed supplement and the feed refusals were obtained after 48 hours in a $60{ }^{\circ} \mathrm{C}$ oven. The chemical composition of the hay and the supplement was determined according to the method of Van Soest et al. [20] for fibres and by the Kjeldhal method for crude protein.

Two analyses of variance with the SAS general linear model [17] were carried out to determine either the effect of the energy level of the diet or that of litter size in trials 1 and 2, respectively. The individual performances of the ewes were analysed with the models including also season, parity, intake level and body condition. The analyses of the growth performances of the lambs also took into account the sex and the birth weight covariable.

\section{RESULTS}

\subsection{Intake}

All the supplement distributed was consumed. The average levels of hay intake were lower $(P<0.01)$ for females suckling a lamb and fed $\mathrm{H}$ rations, compared to the intake levels of A- and L-fed ewes: 305, 615 and $650 \mathrm{DM} \cdot \mathrm{d}^{-1}$, respectively. However, the total fodder intake, taking into account the proportion of alfalfa in the supplement, was 695, 862 and $836 \mathrm{~g} \mathrm{DM} \cdot \mathrm{d}^{-1}$, respectively. The intake levels (Tab. IV) varied from 75 to $98 \mathrm{~g} \mathrm{DM} \cdot \mathrm{kg}^{-1} \mathrm{LW}^{0.75}$ depending on the supplement level of ewes rearing single lambs. They reached $112 \mathrm{~g}$ $\mathrm{DM} \cdot \mathrm{kg}^{-1} \mathrm{LW}^{0.75}$ for $\mathrm{H}$ ewes rearing twin or triple lambs. Intake was higher $(P<0.01)$ on average during the $\mathrm{S} 1$ season than during the $\mathrm{S} 2$ season: $+22 \%$. Taking into account the energetic value, the intake was 1.97 , 1.47 and $1.22 \mathrm{UFL} \cdot \mathrm{d}^{-1}$ for $\mathrm{H}-, \mathrm{A}-$ and L-fed ewes, respectively.

\subsection{Effects of the energy level of the diet}

The average milk production between the 3rd and the 6th week of lactation was 1142,1415 and $1518 \mathrm{~g} \cdot \mathrm{d}^{-1}$ of milk for L-, A- and H-fed ewes, respectively (Tab. V). The H-fed ewes had a 35\% lower milk production $(P<0.05)$ than the other two groups. The variations in scores (Tab. V) were -1.3, -0.1 and +1.1 for the L-, A- and H-fed ewes, 
Table IV. Intake levels (DM.kg ${ }^{-0.75}$ ) and nutritional content of the diet of Martinik ewes, depending on the size of the litter and the supplement level during seasons S1 and S2 and throughout the whole trial.

\begin{tabular}{|c|c|c|c|c|c|}
\hline \multirow[b]{2}{*}{ Group* } & \multicolumn{2}{|c|}{ Total intake $\left(\mathrm{g} \mathrm{DM} \cdot \mathrm{kg} \mathrm{LW}^{-0.75}\right)$} & \multicolumn{2}{|c|}{ Nutritional intake $\cdot \mathrm{d}^{-1}$} & \multirow[b]{2}{*}{ PDI g } \\
\hline & Season 1 & Season 2 & Mean & UFL & \\
\hline Single L & $85.5^{\mathrm{a}}$ & $63.6^{\mathrm{b}}$ & 74.6 & 1.22 & 108 \\
\hline Single A & $87.2^{\mathrm{a}}$ & $79.3^{\mathrm{b}}$ & 83.2 & 1.47 & 134 \\
\hline Single $\mathrm{H}$ & $107.7^{\mathrm{a}}$ & $88.0^{\mathrm{b}}$ & 97.8 & 1.97 & 191 \\
\hline Twins H & $115.5^{\mathrm{a}}$ & $107.4^{\mathrm{a}}$ & 111.4 & 2.17 & 203 \\
\hline Triplets H & $124.8^{\mathrm{a}}$ & $99.3^{\mathrm{b}}$ & 112.0 & 2.14 & 201 \\
\hline
\end{tabular}

* L, A and $\mathrm{H}$ mean low, adjusted and high energy supplement levels, respectively.

Season 1 and season 2: the trials were repeated in two successive lambing seasons with different ewes.

The values on the same lines, followed by different letters differ significantly: $P<0.05$.

Table V. Estimates of performances of Martinik ewes suckling a lamb: milk production from 3 to 6 weeks of lactation (MP, $\mathrm{g} \cdot \mathrm{d}^{-1}$ ); body condition score at the beginning and end of the experiment (BCS), variation in live weight of the mothers $\left(\mathrm{LW} \cdot \mathrm{g}^{-1}\right)$ and average daily weight gain of the lambs (DWG, $\mathrm{g} \cdot \mathrm{d}^{-1}$ ) according to the supplement level.

\begin{tabular}{lccc}
\hline Energy supplement level & Low & Adjusted & High \\
\hline Milk production $\left(\mathrm{g} \cdot \mathrm{d}^{-1}\right)$ & $1142^{\mathrm{a}}$ & $1415^{\mathrm{b}}$ & $1518^{\mathrm{c}}$ \\
BCS during lactation & & & \\
$\quad$ At the beginning & $3.1^{\mathrm{a}}$ & $2.9^{\mathrm{a}}$ & $3.0^{\mathrm{a}}$ \\
$\quad$ At the end & $1.8^{\mathrm{a}}$ & $2.8^{\mathrm{b}}$ & $4.1^{\mathrm{c}}$ \\
LW variation of the ewes $(\mathrm{kg})$ & $-1.6^{\mathrm{a}}$ & $+0.5^{\mathrm{b}}$ & $+4.4^{\mathrm{c}}$ \\
DWG of the lambs $\left(\mathrm{g} \cdot \mathrm{d}^{-1}\right)$ & $211^{\mathrm{a}}$ & $219^{\mathrm{a}}$ & $244^{\mathrm{b}}$ \\
\hline
\end{tabular}

The values on the same lines, followed by different letters, differ significantly: $P<0.01$.

respectively. The variation in weight of the females was $-1.6,+0.5$ and $+4.4 \mathrm{~kg}$ between the beginning and end of the trial for levels $\mathrm{L}$, A and $\mathrm{H}$, respectively $(P<0.001)$.

The initial and final weight as well as the DWG of the lambs are given in Table V. The lambs fed the $\mathrm{H}$ diet grew more $\left(248 \mathrm{~g} \cdot \mathrm{d}^{-1} ; P<0.05\right)$ than those fed the other two diets throughout the experiment (211 and $219 \mathrm{~g} \cdot \mathrm{d}^{-1}$ for L- and A-fed lambs, respectively). Growth was higher in males $(+15.8 \% ; P<0.01)$ than in females whatever the supplement level of the ewes and the lactation stage.

\subsection{Effects of litter size}

The mean milk production (Tab. VI) of single-suckling ewes was lower $(P<0.05)$ than that of ewes suckling twins or triplets: 1548 vs. 1956 and $1941 \mathrm{~g} \cdot \mathrm{d}^{-1}$, respectively. The body condition scores (Tab. VI) only decreased for ewes suckling triplets. The females gained weight but these variations were not significant.

The individual rate of growth throughout the duration of the trial (Tab. VI) reached on average 251,198 and $113 \mathrm{~g} \cdot \mathrm{d}^{-1}$ $(P<0.001)$ for single, twin and triplet 
Table VI. Estimates of performances of Martinik ewes fed a high energy supplement according to litter size: average milk production from 3 to 6 weeks of lactation (MP, $\left.\mathrm{g} \cdot \mathrm{d}^{-1}\right)$; body condition score at the beginning and end of the experiment and daily weight gain of the lambs (DWG, $g \cdot d^{-1}$ ).

\begin{tabular}{lccc}
\hline Size of the litter & Single & Twins & Triplets \\
\hline Milk production $\left(\mathrm{g} \cdot \mathrm{d}^{-1}\right)$ & $1548^{\mathrm{a}}$ & $1956^{\mathrm{b}}$ & $1941^{\mathrm{b}}$ \\
BCS during lactation & & & \\
At the beginning & $3.1^{\mathrm{a}}$ & $2.9^{\mathrm{a}}$ & $2.6^{\mathrm{b}}$ \\
At the end & $4.1^{\mathrm{A}}$ & $3.1^{\mathrm{B}}$ & $1.8^{\mathrm{C}}$ \\
DWG of the lambs $\left(\mathrm{g} \cdot \mathrm{d}^{-1}\right)$ & $251^{\mathrm{A}}$ & $198^{\mathrm{B}}$ & $113^{\mathrm{C}}$ \\
\hline
\end{tabular}

The values on the same line followed by different letters differ significantly: $\mathrm{a}, \mathrm{b}$ and $\mathrm{c}: P<0.05$; $\mathrm{A}, \mathrm{B}$ and C: $P<0.01$

Table VII. Daily weight gain $\left(\mathrm{g} \cdot \mathrm{d}^{-1}\right)$ of the litter of Martinik ewes fed the $\mathrm{H}$ diet, depending on the size of the litter and the stage of lactation.

\begin{tabular}{|c|c|c|c|c|}
\hline \multirow[b]{2}{*}{ Litter } & \multicolumn{4}{|c|}{ Weeks of lactation } \\
\hline & 3 & 4 & 5 & 6 \\
\hline Single & $243^{\mathrm{a}}$ & $243^{\mathrm{a}}$ & $266^{\mathrm{a}}$ & $280^{\mathrm{a}}$ \\
\hline Twins & $468^{\mathrm{b}}$ & $285^{\mathrm{b}}$ & $396^{\mathrm{b}}$ & $421^{\mathrm{b}}$ \\
\hline Triplets & $283^{c}$ & $292^{\mathrm{b}}$ & $351^{\mathrm{c}}$ & $397^{b}$ \\
\hline
\end{tabular}

For the same column, the values followed by different letters differ significantly $(P<0.05)$.

lambs, respectively. The DWG of the litter is given in Table VII. The twin litters have a growth rate close to $400 \mathrm{~g} \cdot \mathrm{d}^{-1}$. Triplets have an intermediate DWG. The live weight and DWG were lower in the second than in the first season (Fig. 1).

\section{DISCUSSION}

Hay intake was lower in season 2. The second series took place in more humid conditions when the animals ate less, which is in agreement with the conclusions of Leng [12] for ruminants in hot and humid environments. The increase in the quantity of supplement dry matter offered (of L and $\mathrm{H}$ groups) resulted in a decrease in the intake of hay dry matter, which reached only $15 \%$ of the total intake. This is a classic phenomenon of substitution observed when mixed diets are distributed to animals [5, $6]$. However, it should be noted that the supplement distributed in our experimental conditions had an extremely fibrous composition, due to the incorporation of alfalfa pellets.

Milk production followed the same pattern as the supplement levels. On the one hand, the mean difference in production between the $\mathrm{A}$ and $\mathrm{H}$ diets was small $\left(100 \mathrm{~g} \cdot \mathrm{d}^{-1}\right)$. On the other hand, the difference observed between the $\mathrm{L}$ and $\mathrm{A}$ diets amounted to $270 \mathrm{~g}$ of milk. It therefore seems that the high supplement levels are excessive for the milk production of ewes suckling single lambs, considering the very small surplus of milk observed. The A diet thus seems well adapted to optimal milk production. If we compare the performances of females rearing single lambs and fed an $\mathrm{L}$ diet with those obtained $\left(780 \mathrm{~g} \cdot \mathrm{d}^{-1}\right)$ by Blackbelly ewes reared in tropical conditions on pasture without adding any supplement [9], the supplement proves to be of undeniable interest since it produced a $46 \%$ gain of milk. The small amount of additional milk obtained for $\mathrm{H}$-fed ewes has also been observed by Aboul-Naga et al. [1], who measured only a $9 \%$ milk supplement for a diet providing $125 \%$ of production requirements. 

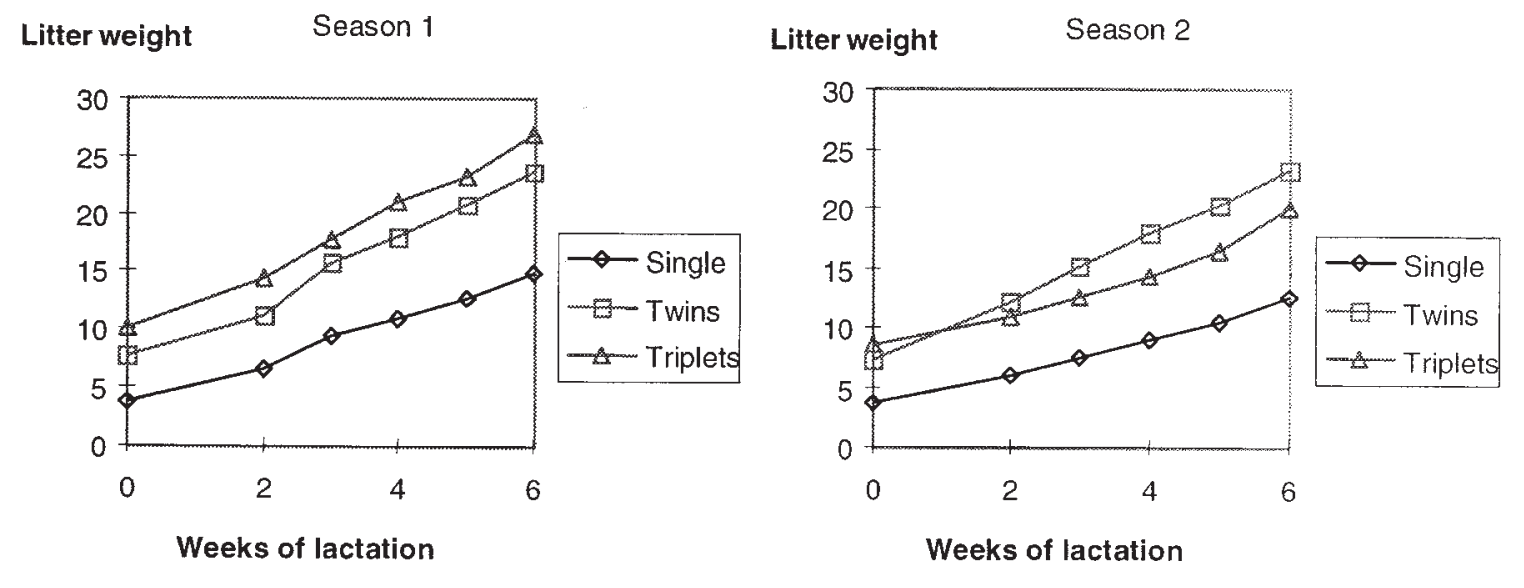

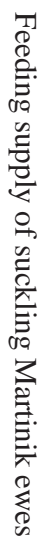

Figure 1. Evolution of the weight of litters of Martinik ewes in the middle of lactation according to litter size and lambing season. 
The H-fed ewes rearing single lambs became fatter and heavier. This reinforces the hypothesis of an excessive consumption compared with requirements. On the contrary, the decrease in the body score of L-fed females shows that these ewes had to mobilise their body reserves.

The results of lamb growth were more or less identical whatever the diet of the ewes, undoubtedly because the lambs had access to supplementary food. In the case of selective intake of the lambs suckled by their mothers, the L diet could be given to ewes since the lambs reached a good level of growth. However, the advantage of the $\mathrm{L}$ diet is tempered by the fact that the ewes lost weight. A drop in body condition could have repercussions on their ability to reproduce subsequently $[13,18]$, which would reduce the productivity of Martinik ewes which follow a semi-intensive reproduction rhythm. These considerations favour the A diet for females suckling single lambs, since it allows both good levels of milk production and growth and it maintains the body condition of females.

Milk production increased with the size of the litter between single lambs and twins, in agreement with the results in other studies conducted in tropical regions [2, 3, 19]. Supplementing diets of Martinik ewes suckling twins resulted in a 50\% increase in milk compared to the milk production from days 0 to 70 of $1245 \mathrm{~g} \cdot \mathrm{d}^{-1}$ observed for the same animals reared on irrigated pasture without any supplements [14]. A high energy level can be justified in the case of ewes with twins since their milk production increased by nearly $2 \mathrm{~kg} \cdot \mathrm{d}^{-1}$ and the DWG of the litter reached $400 \mathrm{~g}$. Furthermore, their body condition at the end of lactation enables them to start a new reproduction cycle in good conditions.

\section{CONCLUSION}

The results obtained in these trials make it possible to formulate dietary recommendations for intensive suckling sheep farming in tropical areas where few studies have been conducted on nutrition. In intensive breeding conditions, recommended daily energy allowances taking into account a good BCS of ewes for successive reproduction are 1.47 UFL for single-suckling ewes and 2.17 UFL for twin-suckling ewes, in order to enable a DWG of the litter of 250 and $400 \mathrm{~g} \cdot \mathrm{d}^{-1}$, respectively. On the other hand, the data enable a better assessment of the production potential of these local genotypes. The level of performance is high and requires large supplies of nutrients. Supplement strategies still have to be defined in tropical farming systems to optimise the available fodder biomass, reduce the cost of supplementary feed and maintain high levels of production.

\section{ACKNOWLEDGEMENTS}

The authors would like to thank E. Depres, P. Despois, D. Feuillet, C. Jacquet-Cretides, M. Jean-Bart, F. Pericarpin, L. Philibert and G. Saminadin for their technical help. They are grateful to Dr. C. Demarquilly for corrections to the manuscript and to $\mathrm{C}$. Young for translations.

\section{REFERENCES}

[1] Aboul-Naga A.M., El-Shobokshy A.S., Marie I.F., Moustafa M.A., Milk production from subtropical non-dairy sheep. I. Ewe performance, J. Agric. Sci. (Camb.) 97 (1981) 297-301.

[2] Amégée Y., Le mouton de Vogan (croisé Djallonké $\times$ Sahélien) au Togo. I. La production lactée et ses relations avec la croissance des agneaux, Rev. Elev. Mèd. Vét. Pays Trop. 37 (1984) 82-90

[3] Amégée Y., Étude de la production laitière de la brebis Djallonké en relation avec la croissance des agneaux, Rev. Elev. Mèd. Vét. Pays Trop. 37 (1984) 331-335.

[4] Aumont G., Caudron I., Xandé A., Tables des valeurs alimentaires des fourrages tropicaux de la Zone Caraïbe et de la Réunion, INRA Édition, SRZ, Guadeloupe, 1991.

[5] Berge P., Dulphy J.P., Étude des interactions entre fourrage et aliment concentré chez le mouton. I. Facteurs de variation du taux de substitution, Ann. Zootech. 34 (1985) 313-334. 
[6] Berge P., Dulphy J.P., Étude des interactions entre fourrage et aliment concentré chez le mouton. II. Facteurs de variation de la digestibilité, Ann. Zootech. 40 (1991) 227-246.

[7] Bocquier F., Thériez M., Prache S., Brelurut A., Alimentation des ovins, in: Jarrige R. (Ed.), Alimentation des bovins, ovins et caprins, INRA, Paris, 1988, pp. 249-279.

[8] Doney J.M., Peart J.N., Smith W.F., Louda F., A consideration of the techniques for estimation of milk yield by suckled sheep and a comparison of estimates obtained by two methods in relation to the effect of breed, level of production and stage of lactation, J. Agric. Sci. (Camb.) 92 (1979) 123-132.

[9] Godfrey R.W., Gray M.L., Collins J.R., Lamb growth and milk production of hair and wool sheep in a semi-arid tropical environment, Small Ruminant Res. 24 (1997) 77-83

[10] INRA, Alimentation des Ruminants, INRA Publications, Paris, 1988.

[11] Leimbacher F., La sélection du mouton Martinik, INRA, Guadeloupe, 1996.

[12] Leng R.A., Factors affecting the utilization of "poor-quality" forages by ruminants particularly under tropical conditions, Nut. Res. Rev. 3 (1990) 277-303.

[13] Lindsay D.R., Martin G.B., Williams I.H., Nutrition and reproduction, in: King G.J. (Ed.), Reproduction in domesticated animals, World animal science Series Amsterdam, The Netherlands, Elsevier Science Publishing Company Inc, 1993, pp. 459-491.

[14] Mahieu M., Aumont G., Alexandre G., Élevage intensif des ovins tropicaux à la Martinique, INRA Prod. Anim. 10 (1997) 21-32.

[15] Navès M., Alexandre G., Leimbacher F., Mandonnet N., Menendez-Buxadera A., Avances en los programas de gestion de los recursos geneticos en los rumiantes del Caribe, in IV congreso iberoamericano de razas autóctonas y criollas, Tamaulipás, Mexico, 1998, pp. 78-92.

[16] Russel A.J.F., Doney J.M., Gunn R.G., Subjective assessment of body fat in live sheep J. Agric. Sci. (Camb.) 72 (1969) 451-454.

[17] SAS, SAS user's guide, Statistics, SAS inst., Inc. Cary, NC, 1988.

[18] Thériez M., Influence de l'alimentation sur les performances de reproduction des ovins, in: $9^{\text {es }}$ Journées ovine et caprine, INRA-ITOVIC, Paris, 1984, pp. 294-326.

[19] Torres-Hernandez G., Hohenboken W., Relationships between ewe milk production and composition and preweaning lamb weight gain, J. Anim. Sci. 50 (1980) 597-602.

[20] Van Soest P.J., Robertson J.B., Lewis B.A., Methods for dietary fiber, neutral detergent fiber, and nonstarch polysaccharides in relation to animal nutrition, J. Dairy Sci. 74 (1991) 3583-3597. 